\title{
Epidemiology and Estimated Cost of Microsurgical Treatment of Peripheral Nerve Tumor Conducted by the Brazilian Unified Health Care System (2008-2016)
}

\section{Epidemiologia e estimativa de custos do tratamento microcirúrgico dos tumores de nervos periféricos conduzidos pelo Sistema Único de Saúde (2008-2016)}

\author{
Marcelo José da Silva de Magalhães ${ }^{1,2,3}$ Mayallu Almeida Mendes ${ }^{2}$ Henrique Nunes Pereira Oliva ${ }^{3}$ \\ ${ }^{1}$ Department of Neurosurgery, Hospital Vila da Serra, Belo Horizonte, \\ MG, Brazil \\ ${ }^{2}$ Medical School, Faculdades Unidas do Norte de Minas, Montes

\begin{abstract}
Address for correspondence Marcelo José da Silva de Magalhães, MD, Francisco Versiane Ataíde Street, 760, apt.1301, Montes Claros, Minas
\end{abstract} \\ Gerais, 34401-039, Brazil (e-mail: marcelo7779@yahoo.com.br).
} Claros, MG, Brazil

${ }^{3}$ Medical School, Faculdades Pitágoras, Montes Claros, MG, Brazil

Arq Bras Neurocir 2019;38:112-116.

\begin{abstract}
Introduction Primary nerve tumors correspond to $\sim 5 \%$ of the soft tissue neoplasms affecting the upper limbs, with benign lesions being more frequent than malignant lesions.

Objective To describe the epidemiological data of the microsurgical treatment of peripheral nerve tumors performed by the Brazilian Unified Health System (SUS, in the Portuguese acronym), with the code 0403020131, from 2008 to 2016, regarding the number of annual procedures, hospital and professional expenses, the average duration of hospital stay, and the number of deaths.

Methods This is a descriptive epidemiological study whose data were obtained by consulting the database provided by the Health Informatics Department of the Brazilian Ministry of Health (DATASUS, in the Portuguese acronym).

\section{Keywords}

- epidemiology

- costs

- peripheral tumor nerve

- microsurgery

- tumor-like lesions

Resumo

Results/Discussion A total of 6,012 procedures were performed during the period studied, with an average of 688 procedures per year. The average hospital stay was of 2.13 days. There was no mortality rate. The average annual cost of the professional was BRL 50,091.45; and the average hospital expenses were BRL111,887.94.

Conclusion The microsurgical treatment of peripheral nerve tumors is a safe surgical procedure with zero mortality rate and short hospital stay. There was no national data on tumors of this nature in the medical literature.

Introdução Os tumores primários de nervos periféricos correspondem a 5\% dos tumores de tecidos moles dos membros superiores, dentre os quais os de natureza benigna são os mais frequentemente encontrados.
\end{abstract}

received

November 21, 2018

accepted

February 19, 2019
DOI https://doi.org/

10.1055/s-0039-1685219.

ISSN 0103-5355.
Copyright (e 2019 by Thieme Revinter

Publicações Ltda, Rio de Janeiro, Brazil
License terms

(c) $(1) \$$ 


\section{Palavras-chave \\ - epidemiologia \\ - custos \\ - tumor periférico \\ - nervo \\ - microcirurgia \\ - lesões pseudotumorais}

Objetivo Descrever os dados epidemiológicos do tratamento microcirúrgico de tumores de nervos periféricos realizados pelo Sistema Único de Saúde (SUS), código 04.03.02.01-31, de 2008 a 2016, referente ao número de procedimentos anuais, às despesas hospitalares e profissionais, ao tempo de internação e ao número de óbitos. Métodos Trata-se de um estudo epidemiológico descritivo cujos dados foram obtidos através do Departamento de Informática do Ministério da Saúde do Brasil (DATASUS). Resultados/Discussão Um total de 6.012 procedimentos foram realizados durante $o$ período estudado, com uma média de 688 procedimentos por ano. A permanência hospitalar média foi de 2,13 dias, com mortalidade nula durante o período do estudo. 0 custo médio anual com o profissional médico foi de $R \$ 50.091,45$, e de $R \$ 111.887,94$ com despesas hospitalares.

Conclusão O tratamento microcirúrgico dos tumores nervosos periféricos é um procedimento cirúrgico seguro. Trata-se de um procedimento com taxa de mortalidade nula e curta permanência hospitalar. Notou-se uma ausência de trabalhos nacionais com dados epidemiológicos sobre os tumores desta natureza.

\section{Introduction}

Peripheral nerves have as predominant supporting elements the connective tissue stroma and Schwann cells. When an axon is involved through multiple spirals by a Schwann cell, it is said to be myelinated. If a Schwann cell involves many axons simultaneously, it constitutes an unmyelinated fiber. Each nerve is composed of the epineurium, a sheath of thick connective tissue, and of the perineurium, a fibrous stroma that surrounds groups of axons forming multiple bundles of nerve fibers. ${ }^{1}$

Among the lesions that can affect the peripheral nerves, primary neural tumors represent $\sim 5 \%$ of the soft tissue neoplasms of the upper limbs. ${ }^{2,3}$ The main peripheral nerve tumors and tumor-like lesions are: traumatic neuromas, Morton neuromas, neural fibrolipomas, nerve sheath ganglions, benign peripheral nerve sheath tumors (PNSTs), schwannomas, neurofibromas, and malignant neoplasms called malignant PNSTs. ${ }^{1}$ Benign nerve tumors are much more common than malignant ones, with schwannomas and neurofibromas representing the most frequent neoplasms. ${ }^{4}$

Peripheral nerve tumors can occur in various regions of the body, such as in the flexor regions of the extremities, in the head and cervical regions, in the retroperitoneal space, and in the dorsal roots of the spinal nerves. These regions may have some influence in terms of the technique and approach involved in the surgical treatment and of the prognosis. ${ }^{1,5}$

The objective of the present study is to describe the epidemiological data regarding the number of annual procedures, hospital and professional expenses, the mean length of hospital stay, and the number of deaths of patients admitted by the Brazilian Unified Health System (SUS, in the Portuguese acronym), in the period from 2008 to 2016, using the code of microsurgical treatment of peripheral nerve tumor/neuroma. The present study will also evaluate the impact of inflation on professional spending during the period studied.

\section{Methodology}

This is a descriptive epidemiological study, whose data were obtained by consulting the database provided by the Health Informatics Department of the Brazilian Ministry of Health (DATASUS, in the Portuguese acronym), at the website (http://www.datasus.gov.br), accessed in February 2017. The present study consisted of all cases of patients submitted to treatment with the code: microsurgical treatment of peripheral nerve/neuroma tumor (0403020131), from January 2008 to December 2016. It was not necessary to submit the project to the Research Ethics Committee because it is a public domain bank. Subsequently, a bibliographic research was conducted in the PubMed scientific database, searching for Brazilian and foreign publications, with the following descriptors: peripheral nerves, tumor, schwannomas, and surgery.

The inclusion criteria used were: indexed journals published in national and international journals, written in English and in Portuguese. The exclusion criteria took into consideration the articles whose titles and abstracts did not fit the research objectives. From the defined strategy, the bibliographic search resulted in a final sample consisting of nine publications indexed at PubMed. The studies were carefully read in their entirety and selected because they strictly met the inclusion criteria and were considered relevant to be part of the proposed study.

To calculate the impact of inflation on the surgical codes during the period studied period, the Brazilian National Extended Consumer Price Index (IPCA, in the Portuguese acronym). The IPCA was chosen because it is an index that covers families with monthly incomes ranging from 1 to 40 minimum wages, whatever the source of income, and who live in the urban areas of the regions of Brazil. For the calculation of the IPCA, the program was available online through the calculating platform of the citizen of the Central Bank of Brazil, where it was possible to post the value to be corrected, specifying the time interval, as well as the index to 
be used for the correction of the values in Brazilian Reais (BRL). ${ }^{6,7}$

For the conversion of currency from BRL to US Dollars (USD), the quotation was taken on December 8, 2017,, whose exchange value was of USD $1=$ BRL 3.17.

\section{Results}

- Table 1 shows the total number of hospitalizations for the microsurgical treatment of peripheral nerve/neuroma tumors, which occurred between January 2008 and December 2016, totaling 6,012 procedures, with an annual average of 668 procedures. There was a reduction of $9.76 \%$ in the number of treatments performed comparing the years of 2008 and 2016. Most of the treatments occurred in the southeast region (3,421 microsurgeries), and the smallest amount occurred in the northern region (172 microsurgeries), as can be observed in - Table 2 .

According to $\mathbf{- T a b l e ~} \mathbf{3}$, the total cost of hospital services was BRL 1,006,991.50, and the annual average of expenses during the period studied was BRL $111,887.94$. The average cost of hospital services ranged from BRL 94,879.01 in 2011, and the highest annual value in 2008 (BRL 150,418.43). And the highest annual value in 2008 , reflecting a $36.96 \%$. The total cost of professional services during the period studied

Table 1 Annual number of hospitalizations in the Brazilian Unified Health System for the microsurgical treatment of peripheral nerve/neuroma tumors between 2008 and 2016

\begin{tabular}{|l|l|}
\hline Year & Total hospitalizations \\
\hline 2008 & 697 \\
\hline 2009 & 663 \\
\hline 2010 & 629 \\
\hline 2011 & 614 \\
\hline 2012 & 709 \\
\hline 2013 & 699 \\
\hline 2014 & 695 \\
\hline 2015 & 677 \\
\hline 2016 & 629 \\
\hline Total & 6,012 \\
\hline
\end{tabular}

Table 2 Distribution of the total number of microsurgical treatment of peripheral nerve/neuroma tumors between 2008 and 2016, by region of Brazil, in the Brazilian Unified Health System

\begin{tabular}{|l|l|}
\hline Region & Number of procedures \\
\hline North & 172 \\
\hline Central-west & 409 \\
\hline Northeast & 760 \\
\hline South & 1,250 \\
\hline Southeast & 3,421 \\
\hline Total & 6,012 \\
\hline
\end{tabular}

was BRL 450,175.06, and the annual average of these expenses was BRL 50,091.45. When evaluating the value of professional services, there was an oscillation of $56.26 \%$ between 2010, the year with the lowest cost (BRL 36,401.11), and 2014, the year with the higher value (BRL 56.881.68). The highest total annual value of microsurgical treatment of peripheral nerve/neuroma tumors occurred in 2008 (BRL 203,812.29) with an annual average of BRL $161,907.39$.

The mean length of hospital stay is shown in - Table 4. The mean stay between the years analyzed was 2.1 days, with the lowest average in 2014 (1.8 days), and the highest in 2012 (2.6 days). There were no deaths during the period studied.

\section{Discussion}

Schwannomas are the most prevalent peripheral nerve tumors in the upper limbs., ${ }^{2,3}$ They are derivatives of the peripheral nerve sheath, develop eccentrically for nerve fibers, being typically encapsulated by the epineurium, so that they do not perform nerve invasion, only compression. $^{2-4,8}$ They can be diagnosed at any age, but are most common between the ages of 20 and 50 years old. ${ }^{4,8}$ They usually are small, slow-growing, solitary lesions. ${ }^{4,8}$ They can occur anywhere in the body; the most affected sites are the head and the neck, the flexor surfaces of the extremities, the mediastinum, and the retroperitoneum. ${ }^{4}$ The histopathological characteristic of the schwannoma is a biphasic histopathological pattern with highly organized rotating cell areas and less organized, less cellular areas where the myeloid tissue predominates. ${ }^{4}$ Old Schwannoma is the term used for long-standing tumors that are generally relatively large and have undergone degenerative change. ${ }^{4}$ Areas of cyst formation, calcification, hyalinization, and hemorrhage may be evident in histological exams. ${ }^{4}$ Nuclear atypia has been described and can occur in these tumors based on the degenerative process. ${ }^{4}$ Schwannomas are usually not associated with mitotic activity and, therefore, should not be misinterpreted. ${ }^{4}$ These tumors rarely undergo malignant transformation. ${ }^{8}$

Neurofibromas arise from Schwann cells and are also composed of a variety of other cells, including neuronal axons, fibroblasts, mast cells, macrophages, perineural cells, and extracellular matrix materials, such as collagen. ${ }^{5,8,9}$ They are classified into localized or solitary, presenting in plexiform or diffuse forms, ${ }^{8,9}$ with localized being the most common subtype. ${ }^{4,8}$ The tumor tissue is closely associated with the primary nerve and is inseparable from the normal nerve. ${ }^{4,8}$ The lesions of large nerves may remain confined by the epineurium and, therefore, may sometimes be covered by a true capsule. ${ }^{4}$ Most of the lesions originate from small nerves and therefore occur at superficial sites. ${ }^{4}$ Deep-seated tumors are seen as neurofibromas from major nerves. ${ }^{4}$ Neurofibromas are observed in young patients, mainly between 20 and 30 years old. ${ }^{4,8}$ They occur commonly in pictures of neurocutaneous disorders, such as neurofibromatosis type 1 , and $\sim 25 \%$ of the symptomatic neurofibromas affect the head and neck region. ${ }^{5}$ They are commonly 
Table 3 Distribution of costs in Brazilian Reais and in US Dollars involved with microsurgical treatment of peripheral nerve/ neuroma tumors between 2008 and 2016, in the Brazilian Unified Health System

\begin{tabular}{|l|l|l|l|l|l|l|}
\hline Year & $\begin{array}{l}\text { Total amount } \\
\text { in total in Reais }\end{array}$ & $\begin{array}{l}\text { Total Amount } \\
\text { in US Dollars }\end{array}$ & $\begin{array}{l}\text { Value of Hospital } \\
\text { Services in Reais }\end{array}$ & $\begin{array}{l}\text { Value of Hospital } \\
\text { Services in } \\
\text { US Dollars }\end{array}$ & $\begin{array}{l}\text { Value } \\
\text { Professional } \\
\text { Services } \\
\text { in Reais }\end{array}$ & $\begin{array}{l}\text { Value } \\
\text { Professional } \\
\text { Services in } \\
\text { US Dollars }\end{array}$ \\
\hline 2008 & BRL $203,812.29$ & USD 64,294.09 & BRL 150,418.43 & USD 47,450.60 & BRL 53,393.86 & USD 16,843.48 \\
\hline 2009 & BRL 172,458.93 & USD 54,404.44 & BRL 127,696.65 & USD 40,282.85 & BRL 44,762.28 & USD 14,120.59 \\
\hline 2010 & BRL 137,835.52 & USD 43,481.23 & BRL 101,434.41 & USD 31,998.23 & BRL 36,401.11 & USD 11,483.00 \\
\hline 2011 & BRL 139,311.68 & USD 43,946.90 & BRL 94,879.01 & USD 29,930.28 & BRL 44,432.67 & USD 14,016.61 \\
\hline 2012 & BRL 154,655.21 & USD 48,787.13 & BRL 101,633.74 & USD 32,601.11 & BRL 53,021.47 & USD 16,726.01 \\
\hline 2013 & BRL 162,538.04 & USD 51,273.82 & BRL 108,475.65 & USD 34,219.44 & BRL 54,062.39 & USD 17,054.38 \\
\hline 2014 & BRL 166,397.68 & USD 52,491.38 & BRL 109,516.00 & USD 34,547.63 & BRL 56,881.68 & USD 17,943.74 \\
\hline 2015 & BRL 155,921.61 & USD 49,186.62 & BRL 103,032.84 & USD 32,502.84 & BRL 52,888.77 & USD 16,684.15 \\
\hline 2016 & BRL $164,235.60$ & USD 51,809.33 & BRL 109,904.77 & USD 34,670.27 & BRL 54,330.83 & USD 17,139.06 \\
\hline TOTAL & BRL 1,457,166.56 & USD 459,673.99 & BRL 1,006,991.50 & USD 317,662.93 & BRL 450,175.06 & USD 142,011.33 \\
\hline
\end{tabular}

Abbreviations: BRL, Brazilian Reais; USD, US Dollars.

referred to as painless, well-defined, fusiform or round, slowgrowing masses $<5 \mathrm{~cm}$ in diameter. ${ }^{4,8}$ Histologically, they are composed of elongated cells mixed with undulating bundles of collagen and/or of mucin. ${ }^{4}$

Peripheral nerve tumors are usually asymptomatic, though the symptoms appear when the lesions grow and produce mass effect, being able to generate edema, paresthesia, loss of muscle strength, and pain., ${ }^{2,5}$ The Tinel sign is usually present around the tumor. ${ }^{2}$ In case of involvement of the vagus nerve, they can cause dysphagia. ${ }^{5}$ Even with a positive sign, paresthesias and transverse mobility, the clinical identification is somewhat subjective and, for this reason, nerve tumors are often misdiagnosed because of similarities with other soft tissue tumors such as lipomas, fibromas, ganglions, or xanthomas. ${ }^{2}$

Although neurogenic tumors can be diagnosed on magnetic resonance imaging (MRI), it is difficult to differentiate between schwannomas and neurofibromas. ${ }^{8}$ Schwannomas

Table 4 Mean distribution of the days of stay in the hospital referring to the microsurgical treatment of peripheral nerve/ neuroma tumors between 2008 and 2016 in the Brazilian Unified Health System

\begin{tabular}{|l|l|}
\hline Year & Average permanence \\
\hline 2008 & 2.2 \\
\hline 2009 & 2.2 \\
\hline 2010 & 2.1 \\
\hline 2011 & 1.9 \\
\hline 2012 & 2.6 \\
\hline 2013 & 2.2 \\
\hline 2014 & 1.8 \\
\hline 2015 & 2.1 \\
\hline 2016 & 2.1 \\
\hline
\end{tabular}

and neurofibromas share many morphological features in the MRI image. ${ }^{4}$ The presence of target signal, fascicular signal, divided fat signal, and continuity with a peripheral nerve points to a neurogenic origin. ${ }^{8} \mathrm{~A}$ dumbbell shape is typical of paraspinal lesions, which may dilate the intervertebral foramen of a spinal nerve. ${ }^{4}$ With intermuscular localization, lesions may be surrounded by fat, a feature that can create the "split fat signal " in T1-weighted MRI images oriented on the long axis of the affected limb. ${ }^{4}$ In the fluid sequences, the target signal appears with high signal intensity at the periphery and with low signal intensity at the center of the lesion. ${ }^{4,8}$ The intralesional architecture with more myoxoid material peripherally and fibrous tissue centrally allows the presence of the target signal. ${ }^{4,8}$ This radiological sign can be observed in schwannomas, in neurofibromas, and in malignant tumors of the nerve sheath and absent in large masses and in tumors with cystic, hemorrhagic, or necrotic degeneration. ${ }^{4,8}$ The fascicular sign describes multiple ringlike structures within the lesion, possibly reflecting the fascicular bundles seen in histopathological examinations. ${ }^{4,8} \mathrm{~A}$ thin capsule can be identified in T2-weighted images, particularly if the tumor is surrounded by fat, which is more frequent in schwannomas. ${ }^{4,8}$

The surgical removal of schwannomas is usually sufficient to resolve the symptoms. ${ }^{2}$ This type of procedure, however, can cause morbidity in $15.2 \%$ of the patients. As morbidity, it is possible to identify postsurgery the development of new neurological deficits, sensory disturbance, motor weakness, and single wound hematoma. Most of these postsurgery complications are usually temporary. ${ }^{10,11}$

The Brazilian population grew by 14.28 million inhabitants in the period between 2008 and 2016. It is noted that the annual incidence of the peripheral nerve tumors that were surgically treated in 2008 was of 3.63/1 million inhabitants, when the Brazilian population was estimated at 191.8 million, the highest during the studied period, and of 3.05/1 
million inhabitants in 2016, when the population was estimated at 206.8 million, which is the lowest incidence in the study. The annual mean incidence of this microsurgical treatment was of $3.35 / 1$ million inhabitants. A total of 6,012 procedures were performed in the period from January 2008 to December 2016.

The mean length of hospital stay varied between 1.8 days in 2014 and 2.6 days in 2012, with a general average of 2.1 days of hospitalization for the accomplishment of the microsurgical treatment. The death rate was zero during the period studied, corroborating the low mortality rate of the surgical treatment of peripheral nerve tumors.

According to the DATASUS (http://sigtap.datasus.gov.br/ tabela-unificada/app/sec/procedimento/exibir/0403020131/ $02 / 2014)$, the value of transfer to the medical professional for the microsurgical treatment of peripheral nerve in 2008 was BRL 112.00. In the year 2014, after a readjustment of 50\%, it became BRL 168.00. The value continues the same since the last adjustment. After correcting the value since 2008 using the IPCA index, the value should be BRL 195.81 as of December 31, 2016 , and this shows a reduction of $16 \%$.

It is worth noting that the present study under-reports patients who were submitted to treatment of peripheral nerve tumors from the private sector. Another bias of the present study is the presence of patients submitted to surgical treatment of neuromas due to traumatisms such as those found in amputations and in traumatic injuries of the peripheral nerves of the limbs.

As the epidemiological data present in the DATASUS code microsurgical treatment of peripheral nerve/ neuroma tumor includes both surgeries for the treatment of peripheral nerve tumors and tumor-like lesions, this consequently reduces the accuracy of the data presented in the present work.

\section{Conclusion}

The present study reveals that the surgical procedure microsurgical treatment of peripheral nerve/neuroma tumor (0403020131) presented zero mortality rate during the period studied, with a relatively short hospital stay. It was possible to observe an absence of studies with national and international data with epidemiological information on these tumors. The data obtained only reflect the patients coming from the SUS, requiring studies that involve the patients of the private system.

\section{Conflicts of Interests}

The authors have no conflicts of interests to declare.

\section{References}

1 Murphey MD, Smith WS, Smith SE, Kransdorf MJ, Temple HT. From the archives of the AFIP. Imaging of musculoskeletal neurogenic tumors: radiologic-pathologic correlation. Radiographics 1999;19(05):1253-1280

2 Rodrigues AS, Vidinha V, Pinto R, Negrão P. Giant Schwannoma of ulnar nerve: case report. Rev Bras Ortop 2016;52(02):224-227

3 Yang F, Chen XX, Wu HL, et al. Sonographic Features and Diagnosis of Peripheral Schwannomas. J Clin Ultrasound 2017;45(03):127-133

4 Woertler K. Tumors and tumor-like lesions of peripheral nerves. Semin Musculoskelet Radiol 2010;14(05):547-558

5 Bray DP, Chan AK, Chin CT, Jacques L. Large cervical vagus nerve tumor in a patient with neurofibromatosis type 1 treated with gross total resection: case report and review of the literature. J Brachial Plex Peripher Nerve Inj 2016;11(01):e48-e54

6 Brazil. Sistema nacional de índices de preços ao consumidor. Available at: http://www.ibge.gov.br/home/estatistica/indicadores/precos/inpc_ipca/defaultinpc.shtm. Acessed in: June 15, 2017

7 Brazil. BCB- Calculadora do cidadão- Banco Central. Available at: https://www3.bcb.gov.br/CALCIDADAO/publico/exibirFormCorrecao Valores.do? method=exibirFormCorrecaoValores.Acessoem. Accessed in: June 15, 2017

8 Ahlawat S, Chhabra A, Blakely J. Magnetic resonance neurography of peripheral nerve tumors and tumorlike conditions. Neuroimaging Clin N Am 2014;24(01):171-192

9 Lang SS, Zager EL, Coyne TM, Nangunoori R, Kneeland JB, Nathanson KL. Hybrid peripheral nerve sheath tumor. J Neurosurg 2012; 117(05):897-901

10 Desai KI. The surgical management of symptomatic benign peripheral nerve sheath tumors of the neck and extremities: an Experience of 442 Cases. Neurosurgery 2017;81(04):568-580

11 Siqueira MG, Socolovsky M, Martins RS, et al. Surgical treatment of typical peripheral schwannomas: the risk of new postoperative deficits. Acta Neurochir (Wien) 2013;155(09): 1745-1749 